Research, part of a Special Feature on Applied Research for Enhancing Human Well-Being and Environmental Stewardship: Using Complexity Thinking in Southern Africa

\title{
The spread and maturation of strategic adaptive management within and beyond South African national parks
}

\author{
Stefanie Freitag ${ }^{1}$, Harry Biggs ${ }^{2}$ and Charles Breen ${ }^{3}$
}

\begin{abstract}
Natural resource management is embedded within social-ecological environments and requires decisions to be taken within this broad context, including those that pertain to protected areas. This realization has led to South African National Parks adopting a strategic adaptive management approach to decision making. Through narrative, we show why and how this practice has progressively spread and evolved both within the organization and beyond, over the past two decades. A number of catalytic events and synergies enabled a change from reactive tactical management approaches to more inclusive forward-looking approaches able to embrace system complexity and associated uncertainty and change. We show how this long period of innovation has lead to an increased appreciation for the heterogeneous social-ecological system, and for the importance of constructing relationships and colearning, such that organizational transformation has enabled more legitimate and effective operation within an expanding and diversifying constituency.
\end{abstract}

Key Words: adaptive management; colearning; Kruger National Park; protected area stewardship; social-ecological systems; systems thinking

\section{INTRODUCTION}

Protected areas are public assets embedded in a dynamic social context constructed around beliefs, values, and understandings. Multiple stakeholder groups have conflicting interests (Roux and Foxcroft 2011), which often result in tensions at both the management and governance levels as governing assumptions, norms, and values are challenged. In addition, natural resource management is inherently unpredictable (Stankey et al. 2005) and the complex nature of social-ecological systems (Berkes et al. 2002) thus requires decision making with incomplete knowledge. Further, it necessitates that learning is acquired through action and that the emerging new understanding again influences behavior and policy (Rogers 2003). South African National Parks (SANParks) has been practicing a form of adaptive management, called strategic adaptive management (SAM; Rogers and Biggs 1999, Biggs and Rogers 2003, Roux and Foxcroft 2011), which emphasizes the purposeful, participative, forward-planning component of adaptive doing and learning (Grant et al. 2008a, Roux and Foxcroft 2011).

There are relatively few published accounts of long-term applications of SAM or associated adaptive management variants (but see Jones 2009). Our research does not present a new theory or conventional data, but rather uses narrative to document the link between theory and the outcomes of the implementation of that theory over two decades. We show how a favorable synergy between several events and factors led to the development and maturation of the philosophy within SANParks and appears, as a consequence, to have established the concept elsewhere. Rather than attempting traditional evaluation through testing results on 'hard data,' this narrative uses an approach akin to developmental evaluation (Patton 2010) to tell a story of development, change, spread, and adaptation along the journey of mainstreaming adaptive management within SANParks and beyond, providing feedback and enhancing further learning.

\section{THE KRUGER NATIONAL PARK, A PLATFORM FOR CHANGE}

The Kruger National Park (KNP) is an iconic protected area of two million hectares in northeastern South Africa, which forms the boundary with Mozambique and Zimbabwe (Fig. 1). Together with the Limpopo National Park in Mozambique, it forms a critical component of the Great Limpopo Transfrontier Conservation Area, which incorporates the Limpopo River to the north and its major tributary, the Olifants River, further south.

The first moves toward formal protection of the area in 1902 were aimed at protecting dwindling wildlife populations (Carruthers 2007), and early preservationist approaches fostered an organizational culture of tactical response to immediate situations. This paved the way for the style of management by intervention, which arose during the mid 1940s, supported by the establishment of a research section in the park in 1954 (Mabunda et al. 2003). The approach, which persisted until the 1990s, was dominated by assumptions that cause and effect were, to a considerable extent, understood. Over time, decision making and associated outcomes around fire, water, and elephant management in the KNP challenged these assumptions, which set the scene for new and more adaptive approaches.

Fire is considered an important management tool in KNP, initially founded on agricultural approaches. It played an important role in growing and strengthening the relationship between science and management as long-term research into the effects of fire on vegetation (van Wilgen et al. 2003) was founded on a shared concern and environmental ethos, which enabled a culture of adapting management over time (van Wilgen et al. 2007). The history of parallel fire research and management implementation shaped the decision-making culture around aspects of ecosystems management deemed to be within KNP's own control and led to ongoing support of research, even when the research was not immediately applicable (van Wilgen et al.

${ }^{1}$ Scientific Services, South African National Parks, ${ }^{2}$ Conservation Services, South African National Parks, ${ }^{3}$ School of Agricultural, Earth and Environmental Sciences, College of Agriculture, Engineering and Science, University of KwaZulu-Natal 
2007). Early observed vegetation changes in KNP were attributed not only to fire, but also to the effects of increasing elephant populations. Stringent elephant culling was therefore agreed to in the late 1960s based heavily on the work of Van Wyk and Fairall (1969) and was only slightly relaxed in 1986 (Joubert 1986, unpublished manuscript). It was however soon realized that decision making in this domain rested not only within KNP's control as it had for so long with fire management. Instead, public pressure and the lack of rigorous scientific proof of elephants causing unacceptable levels of damage to the KNP vegetation resulted in the discontinuation of culling in 1995.

Fig. 1. Locality map of Kruger National Park in northeastern South Africa, showing its transfrontier context as well as key geographic features that influenced decision making in the region.

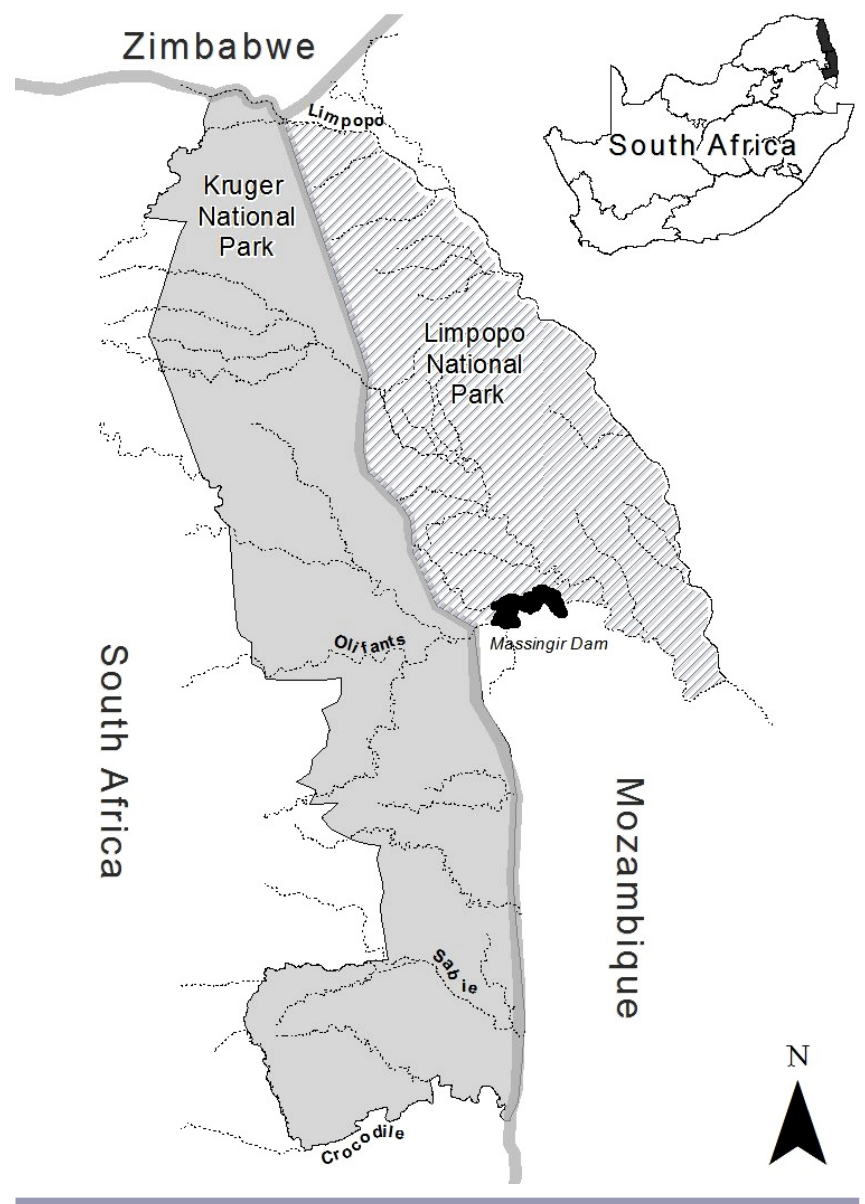

Management responses to the ongoing and long-term deterioration of both river water quality and flow (O'Keeffe and Rogers 2003) were initially also inwardly focused, with attempts at self-reliance through the construction of impoundments and the drilling of wells in KNP (Gaylard et al. 2003). Upstream water user groups successfully competed for their share of the limited resources to the extent that this resulted in periodic cessation of flow in some perennial rivers in KNP (O'Keeffe and Rogers 2003, Pollard et al. 2003). Although these behaviors generally limited the opportunities for building relationships and learning in the region, a small group of upstream irrigation farmers voluntarily reduced water demand during the 1991-1992 drought to sustain flows in the biologically diverse Sabie River (O'Keeffe and Rogers 2003, Biggs et al. 2008). This played an early part in the transformation of attitudes, undermining the island approach to protected area governance at that time by a growing realization that KNP is part of a wider society with diverse value systems (Pollard et al. 2003, 2008).

In addition, university-based scientists conducting research within KNP exposed management to broader paradigm shifts in science (Carruthers 2007). Thus, in the early 1990s, understanding of how KNP ecosystems function had changed (see du Toit et al. 2003) and the existing management strategies aimed at elephant and river challenges were rote. This suggested that mechanistic insular solutions had gone on unquestioned for too long, with limited new learning within an obviously changing system. The two key drivers of change were (1) the start of a paradigm shift toward holistic approaches to managing resources based on the acknowledgement of complex social-ecological systems (Holling 1978, Walters 1986), and (2) the onset of democratic changes in South Africa, which emphasized equity, sustainability, and efficiency in the use of resources. This dynamic environment in the early 1990s prompted an expanded research focus on collaborative decision-making processes for water, arising out of the earlier KNP river research emphasis on the allocation of environmental water flows (O'Keeffe and Rogers 2003). A research program with an adaptive management focus, namely Phase II of the Kruger National Park Rivers Research Program funded by the national Water Research Commission (Breen et al. 2000; Fig. 2), was thus framed in the context of water for conservation, based on the realization that intersector relationships among water users underlay any willingness to compromise and share the scarce resource.

The KNP Rivers Research Program assisted in the development of a shared understanding and appreciation for the often contentious decision-making needs across water users, widening the scope for adaptive management and learning within the water sector. It became clear that enabling relationships were critical, that short-term tactical crisis responses alone were insufficient, that longer-term strategies would be crucial, and that reality appeared more complex than that suggested by sectorial mental models. The collaboration ethic thus shifted to one of shared understanding and building trust, which also opened prospects for organizational changes. The opportunity to institutionalize adaptive management at that time thus grew out of the supportive existing and enabling science-management links in KNP, recognition of the need for integrating the understanding of change in what are now called social-ecological systems, and hopeful signs of potential actual adaptation and response to such change. In addition, the more open communication around water allocation processes in South Africa, and the underlying science basis for the environmental water requirements of river flow regimes, led to wider acceptance and broader social justification thereof.

The KNP managers began to realize and understand the importance of anticipating change and working toward broad desirable goals rather than celebrating specific narrow technical achievements. However, it became evident that making this 
Fig. 2. Simplified chronology of events, experiences, interactions, and influences around the initiation and spread of strategic adaptive management approaches within and around the Kruger National Park through the 1990s. Solid arrows denote direct influence and interaction.

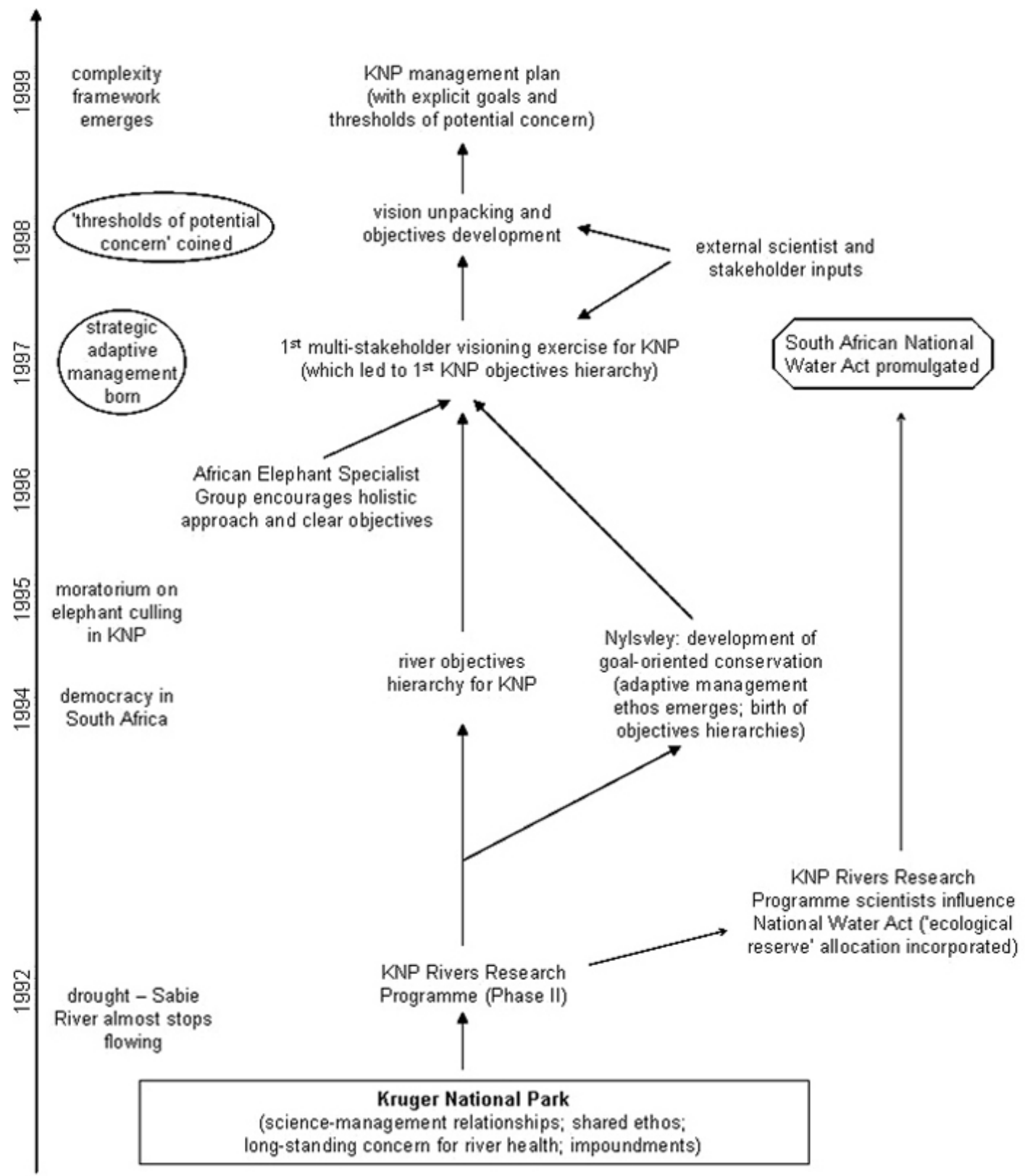

change was difficult and sometimes discouraging, particularly because conservation was relatively unfocussed and weakly conceptualized without explicit goals at that time (Bestbier et al. 1996). A freshwater research collaborator on the KNP Rivers Research Program used ideas from the developing adaptive management process there in a wider protected areas context to establish goal orientation in conservation, prototyped at the provincial Nylsvley Nature Reserve (Bestbier et al. 1996; Fig. 2). Contrary to expectation, the convened group of researchers and managers found it fairly straightforward to define a shared goal, termed the desired state, and laid out a series of steps to help direct and structure the transition. The guidelines of Rogers and Bestbier (1997) constituted the beginning of a shared vocabulary between scientists and managers from different agencies and represented the start of a more explicit and defensible framework for conservation in South Africa, embracing the broader socialecological context through explicit inclusion of steps to consider values as well as social, technological, ecological, economic, and political factors. 


\section{Prototyping strategic adaptive management during the 1990s} Political reform in South Africa led to a democratic government in 1994 that espoused the principle of participatory governance. This had important consequences as society recognized its right to participate in decision making concerning protected area management, and as a growing and diverse constituency challenged long-standing conservation values and beliefs underpinning management and governance frameworks. Although adaptive management ideas were promoted for rivers in the mid 1990s, the 1995 moratorium on elephant culling in KNP resulted from scrutiny of the mass culling approach through changing ecological paradigms, pressures on SANParks from the animal rights sector at the time, and additional pressure from the Convention on International Trade in Endangered Species (Braack 1997). Strong interest from external groups, recommendations from the African Elephant Specialist Group of the IUCN in 1996 (Braack 1997, Carruthers et al. 2008; Fig. 2), and the political and emotive prominence of the elephant issue motivated SANParks to advance development and application of adaptive management in the KNP because it recognized the need for a fair and equitable multistakeholder participation process to develop a more holistic vision and high-level objectives for the national park.

The parallel river and elephant management crises in KNP had similar attributes, they could not be viewed in isolation and required broader conceptualization; social issues were important; and explicit objectives were required. The independent processes advanced a common intent (Biggs et al. 2008) in that they highlighted both the limitations of reactive conservation management and the need for a more proactive approach with greater accountability to society. The KNP managers began to generate emergent credibility through the development and sustainment of relationships with an increasing number, size, and complexity of groups across sectors. This catalyzed both conceptual and organizational changes within SANParks because the institution recognized the dynamic interconnectedness between ecological and societal domains. For instance, although ecosystem patches represent spatially explicit expressions of ecological heterogeneity (Kotliar and Wiens 1990) with complex structure and dynamics (Pickett et al. 2003), social realms, or patches, could be envisioned as conceptually explicit, differentiated by values and beliefs. These patches direct how individuals and groups perceive, define, and engage with ecological resources (Bridges 1991) and leverage their respective power bases in society in response to emerging issues. SANParks began to understand the implications of heterogeneous and dynamic relationships between these domains across spatial and temporal scales and understood that managing the conservation estate with increased societal involvement in and expectation from protected areas posed a particular challenge.

The requirement for a structured process for participation and deliberation thus explicitly emerged around 1996-1997 to enable an understanding of the overall social-ecological context in which the KNP, and other national parks, were managed. The KNP turned to the ecosystem management approach advocated by Rogers and Bestbier (1997), which acknowledged the centralities of scale and participation, incorporated societal value systems, and provided management accountability. It was termed strategic adaptive management (SAM) because it emphasized the notion of preparing for the future rather than reacting to the past (Rogers and Bestbier 1997, Rogers and Biggs 1999) and was facilitated through an inclusive process designed to establish a shared vision and hierarchy of objectives, which would direct management toward acceptable and achievable operational goals. A goal maintenance and revision process promoted learning and institutional memory to accommodate ongoing adjustments to emerging conditions and new understandings (Rogers and Bestbier 1997).

In 1997, KNP scientists, managers, and a few external scientists used the SAM process to derive a provisional vision for the park, which was only slightly modified after three public meetings (SANParks 2005, unpublished manuscript). The KNP vision included four key elements namely biodiversity, human benefits, wilderness, and balance, which were surrogates for the values identified by participants in the process (Braack 1997). Park objectives were formulated through numerous workshops and deliberations, which included some external scientists and a spectrum of stakeholders, over a period of nine months (Braack and Novellie 1997). Objectives embraced the notion that the system was dynamic and that system state definition could vary in time and space without compromising the attainment of goals This necessitated monitoring and assessment to flag when the state approached a tipping point or threshold that, once passed, established a new regime with a different structure and function. The need to track change within upper and lower boundaries of acceptability resulted in the term threshold of potential concern (TPC; Fig. 2) in 1998 to reflect the hypothesized upper and lower boundaries of acceptable ecosystem variability that would elicit concern and management response options about directional system change away from intended goals (Braack 1997, Biggs and Rogers 2003). The objectives and TPC end points were returned to public meetings for checking, acceptability, and ratification and became incorporated into the first ever publicly-mandated KNP management plan (Braack 1997). Although this process was initially a response to elephant management concerns in KNP, the outcome draft management plan was conceptualized across a much wider scale, incorporating a fundamentally new adaptive approach to management. This led to numerous immediate changes at various levels, but delays around a few contentious issues led to final approval at governance level only in 1999 (Fig. 2).

The path to adoption of adaptive management in SANParks reflects a mix of intent and serendipity. Opportunities were grasped by those who appreciated that the problems, i.e., rivers drying up and challenges to elephant culling operations, were complex social-ecological issues characterized by uncertainty (Pollard et al. 2008), which lead to synergism between events. Dialogue moved from being parochial to understanding that cause and effect are separated in time and space. Small focused actions offered opportunity for leveraging change, which allowed the fortuitous synergy between a research process and a socially induced process that had political overtones. Spread of the adaptive management philosophy, although conceptually contained by KNP at that time, resulted in (1) an upward connection between park management and broader governance processes; (2) a broader active societal participation in the elephant management debate also supported by the changing political context in South Africa; (3) widened understanding of, 
Fig. 3. The further spread of strategic adaptive management approaches during the second decade, the 2000s. Solid arrows denote direct influence and interaction, and dotted lines show indirect influences.

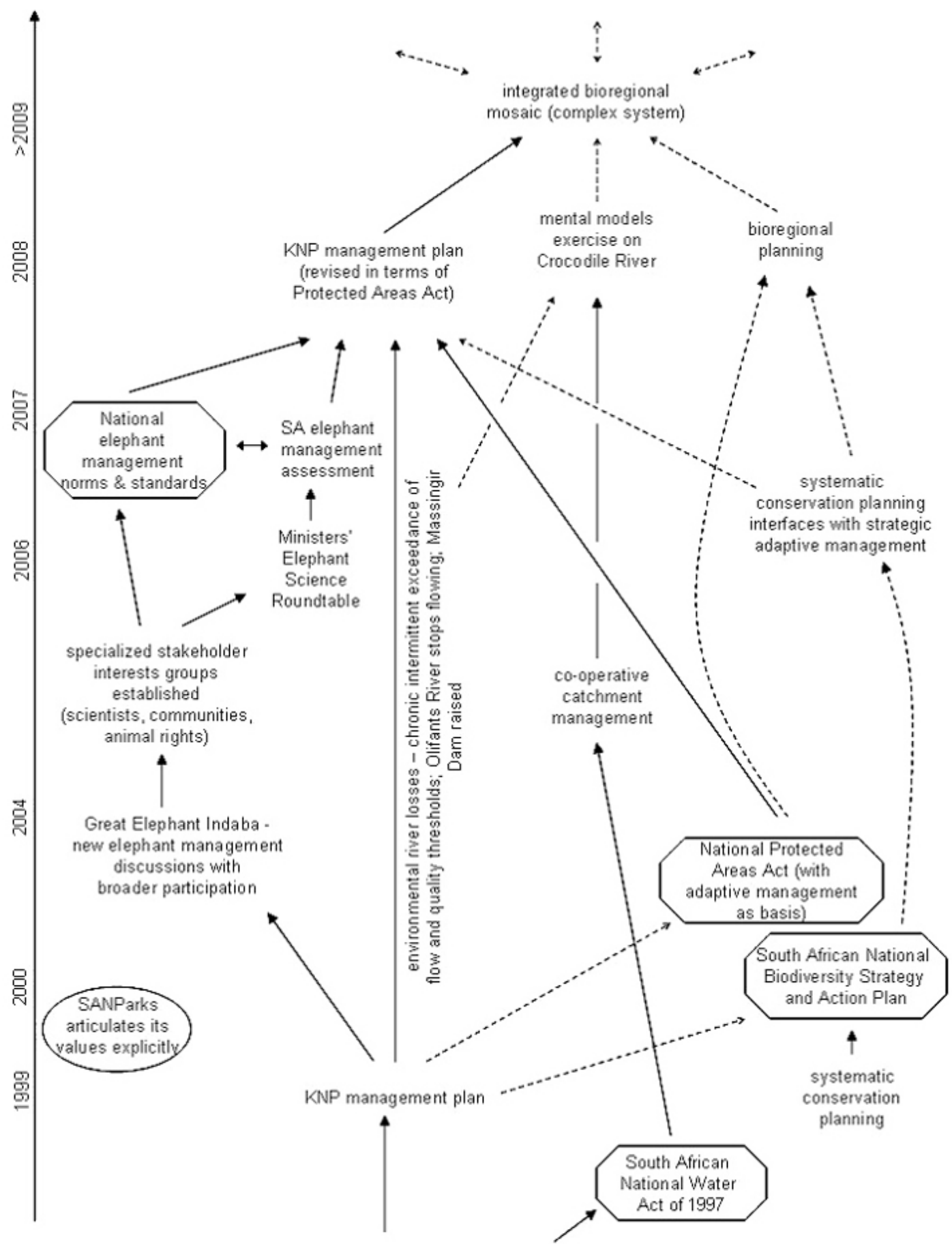

and appreciation for, the inherent uncertainty in conservation management; and (4) recognition that conservation involves a dynamic interface between management and political imperatives. Whereas SAM had been evolving intuitively as a response to complex issues, the process received credibility through growing scientific recognition of complexity as a theoretical framework underlying management of ecological systems (Levin 1999, Holling 2001), coupled with defensible peerreviewed research. 


\section{EXPANDING CONNECTEDNESS AND INFLUENCING GOVERNANCE PROCESSES}

Managers of other regional protected areas initially perceived that the changed management approaches in KNP had little relevance for them. Nevertheless, adoption of SAM by the KNP emphasized the understanding that parks are complex socialecological systems, also necessitating policy changes. Involvement in SAM expanded within SANParks as the organization began setting TPCs to measure unacceptable change in the other ecosystems under its custodianship. At that time, other government agencies, such as the South African National Biodiversity Institute (SANBI), remained concerned with maintaining representative vegetation types through national targets as outlined in the National Biodiversity Strategy and Action Plan (Driver et al. 2005). The operational approach was fundamentally different; SANParks' perspective acknowledged that the state of the system could vary and still retain its essential structure and function, whereas SANBI's coarser national-scale view was that fixed amounts of representative units needed to be conserved. Ongoing interactions between SANParks and SANBI have resulted in the consideration of interlinkages between systematic conservation planning, directed at identification of target biodiversity states (Margules and Pressey 2000, Driver et al. 2005; Fig. 3), and SAM. There is now growing realization that SAM thresholds, delineating the boundaries of the desired state when within it, and systematic conservation planning targets, defining a trajectory toward a desired condition, are similar constructs (Holness and Biggs 2011). In addition, adaptive management principles have been incorporated into South Africa's National Environmental Management: Protected Areas Act (No. 57 of 2003) and subsequent management guidelines (Cowan 2006).

\section{Values and uncertainty}

In 2004, SANParks arranged The Great Elephant Indaba, or open discussion (Grant et al. 2008b, Carruthers et al. 2008; Fig. 3) in an attempt to draw together disparate stakeholder groupings in the elephant management impasse. The indaba showed that widely differing beliefs and perceptions were still held about which values should guide KNP park management. In addition, lack of trust and commonality of vision was evident within the scientific subgroup (SANParks, unpublished manuscript). Two processes enabled scientists to learn together and consider the emerging information and understanding, namely spontaneous widening and strengthening of scientific collaborations and assembly of a science roundtable to advise the national Minister of Environmental Affairs and Tourism on approaches to elephant management (Owen-Smith et al. 2006; Fig. 3). The primary debate revolved around how much change could be accepted before intervention was considered, i.e., the upper and lower TPC boundaries of system state. Once TPCs were framed as testable hypotheses about thresholds and change in the context of park goals and objectives, science and other stakeholders were able to accept that the SAM threshold system at least represented one explicit way of calibrating and recording the reasoning for when management action might or might not be considered. Scientists agreed on the approach, but often not on the actual thresholds or the ability to predict excesses. Nevertheless, an important outcome was that SAM focused and promoted research and dialogue among scientists (Scholes and Mennell 2008), which strengthened relationships and trust.
Charismatic species, such as elephants, are symbols of protected areas, which are founded on the varying belief and value systems of stakeholders. The KNP accepted the imperative of wider stakeholder participation, which involved strengthening relationships among heterogeneous groups, and thus increased relational connectedness (Nkhata et al. 2008). The dialogue process built into SAM brought understandings closer (Rogers and Biggs 1999, Roux and Foxcroft 2011) and made values explicit (Rogers and Bestbier 1997), by recognizing that values cannot always be fully reconciled and that the relative ordering of individual values may change with context and scale. As a result, although some stakeholders may not agree with a decision, they may support the process that led to the decision that conflicts with their espoused values. For this to translate further into successful collaboration, the level of trust and commitment between actors and groups in the social web is crucial (Cullen et al. 2000), but is often lagged as it depends on reconciling deeply embedded terminal values that are slow to change (Rokeach 1973, Fulton et al. 1996).

Embracing complexity, uncertainty, and the experiential nature of knowledge enables an appreciation that thresholds are hypotheses about system change, which may occur over time frames, sometimes spanning multiple generations (see Stockholm Resilience Centre 2013 for examples). These hypotheses, and our associated understanding of change and its manifestation, are therefore expected to be invalid at times, which would require hypotheses to be revised. Thus, for example, knowledge on the interactions between river flow, sand deposition, and the indicator tree, Breonadia salicina, in the Sabie River, was based on 50 years of data (van Coller 1993, Mackenzie et al. 1999) and provided the foundation for hypotheses about river system state and thresholds in the 1990s (McLoughlin et al. 2011). The 1:100 year flood disturbance in February 2000, after the severe drought of 1992 (Rogers and O'Keeffe 2003), necessitated a revised understanding of river variability such that thresholds were adapted (McLoughlin et al. 2011) and explicit consideration of riverupland ecosystem connections across increasing spatial and temporal scales was prompted (Pickett et al. 2003).

\section{Mismatches between institutional and ecosystem scales}

Conceptually, adaptive management implies that park management can take actions believed necessary to cause the system to stay within acceptable limits. However, as river and elephant management highlighted in KNP, many management issues involve changes to biophysical contexts and to other parties operating outside of the boundaries of the protected area. To achieve the intent of adaptive management therefore requires park management to adapt behavior and often also requires that other parties are willing to change their behavior. When the Sabie River almost stopped flowing in the early 1990s, the willingness of a small cohesive group of upstream irrigation farmers to reduce abstraction enabled sustained flow in the KNP because of relationships, understanding, and appreciation for the downstream biological consequences of no flow. In contrast, the much longer perennial Olifants River is highly regulated by dams and weirs, stakeholders are more diverse, and self-interest confounds attempts to institutionalize water sharing. In 2005, this river stopped flowing in KNP for 78 days (McLoughlin et al. 2011) even though monitoring had tracked the rapid deterioration and had predicted flow cessation. The KNP engagement and negotiations with Department of Water Affairs were ineffective 
and merely resulted in a palliative water release from an upstream dam. This lack of response to the declining state of the river within KNP may have been caused by the fact that at that time the SAM process, with stakeholder participation, was perceived as a process developed by and for the national park only. In addition, the mismatch in scale between the mandates of the institutions and the longitudinal river system confounded attempts to achieve integrated management at river scale.

The disconnect between social-ecological systems and governance scales was exemplified by the raising of the wall of the Massingir Dam on the Olifants River in Mozambique, immediately downstream of KNP (Fig. 1). An international treaty was signed in the 1960s based on South Africa's inability to guarantee the river flows Mozambique required. The treaty was legally upheld four decades later, even though circumstances and values had changed significantly. This resulted in back flooding of the Olifants River gorge in KNP. A key failure was the inability to revise decision-making approaches across the international boundary, which suggests inadequate systemicity at this governance level at that critical time. The political imperative to uphold the treaty frustrated KNP's attempts to engage appropriately and to ensure colearning with Mozambican and policy-level stakeholders. Park authorities, operating at much smaller scales, were powerless to influence the larger scale international interinstitutional decision making and were left with reactive mitigatory management approaches. Large-scale crocodile deaths in the back-flooded area since 2008 (C. A. McLoughlin, A. Deacon, and H. Sithole 2009, unpublished manuscript) have more recently resulted in catchment-wide collaborative research and monitoring efforts to evaluate system deterioration.

Efforts to expand and connect conservation areas have resulted in transfrontier parks designed to increase connectivity for wildlife, tourism, and sustained livelihoods. Issues, such as animal and human health, are then scaled up across park, national, and multinational scales. However, the philosophical origins of protected areas have resulted in conventional institutions scaled to function only within the area contained formally in gazetted boundaries, but not necessarily effectively within the larger bioregional context. Because protected areas now often transcend administrative boundaries, the institutional arrangements must foster relationships and operate across scales, and formal structures and rules can no longer be relied on to resolve emerging issues characterized by uncertainty. Rather, as in the Sabie River example, it will be easier to resolve issues when stakeholders acknowledge shared problems and collaborate with experimental solutions, which build and strengthen relationships (Westley and Vredenburg 1997, Kinnaman and Bleich 2004, Nkhata et al. 2008).

\section{SAM SPREADS WITHIN AND BEYOND SANPARKS}

SANParks has become influential as a participant in a wide range of national strategies, including multisector collaborative projects, river health initiatives, the national biodiversity strategy and action plan, and bioregional planning (Fig. 3). The nested subsystems have strong linkages within and between them, and this recognition has enhanced organizational awareness of connectedness with associated feedbacks and lags. SANParks has also moved into a period of implementation, testing, and refinement of the matured SAM approach, with time for critical reflection (Biggs et al. 2011, Foxcroft 2011). The approach has not yet reached the same level of maturity and internalization in all 19 parks under SANParks' custodianship, and we acknowledge these lags in implementation. Nevertheless, adaptive organizational capacity has grown in SANParks, with greater acceptance for learning by experimentation and prototyping, and enhanced preparedness for decision making under conditions of uncertainty (SANParks 2013, Tambling et al. 2013, Pollard et al. 2014). Although concepts of SAM have begun spreading beyond the subcontinent, primarily with some influence on international freshwater initiatives (Kingsford et al. 2011, Kingsford and Biggs 2012), this broader influence is not yet visible in the international literature (Rist et al. 2012).

\section{DISCUSSION AND WAY FORWARD}

Protected areas are viewed variously by their expanding conservation constituencies with differing mental models of how the systems work, and in the light of ecosystem change and of expectations, of the services that these areas should provide, now and into the future. The maintenance of river flow and the management of elephant populations in KNP symbolizes these varying societal concerns and expectations, confounded by the difficulty of understanding and accepting change. The emergence of a more nuanced and better awareness within society of its accountability toward protected areas has enabled SANParks' transformation toward more legitimate operation within an expanding and diversifying constituency in the last two decades.

The narrative shows how several extrinsic and intrinsic drivers changed the KNP management approach from tactical and issues-based to one that explicitly attempted to embrace forward planning, experimentation, and learning. Emergent lessons are: (1) acceptance of the complexity and the imprecise predictability of the greater KNP social-ecological system enabled opportunities to be seized as did crises, disputes, and setbacks; (2) slow, unforced change and patience were invaluable to allow colearning, commitment, and trust to grow and mature to a point in which credible relationships resulted in a willingness to change behaviors in the interest of a common vision; (3) some purposeful delays in decision making permitted understanding to grow as the system revealed more of its nature; (4) the recognition that knowledge is imperfect and constrained by experiences facilitated openness to experimentation and prototyping with a learning outcome; (5) values cannot always be reconciled, but must be made explicit; (6) institutionalization is challenging and requires contextualization and maturation of learning through leadership and committed agents of change, spanning various within- and between- institutional governance levels.

Key challenges along the way have included the paradox of formalizing the SAM process, e.g., with structured decision and feedback loops, (Pollard and du Toit 2007), which requires sufficient informality and freedom to experiment and learn by doing, to deal with the expanded complexities and connections in the social-ecological system. During this time, SANParks was dealing with entrenched beliefs, institutional boundaries, challenges, disputes, successes, and setbacks, while at the same time showing committed leadership, learning, and the construction of relationships. This purposive learning process required both individual and institutional flexibility, a willingness 
to learn and change (Stankey et al. 2005), and letting go of preconceived assumptions at times (Bridges 1991). More recently, context-specific learning has both informed and slowed down the ongoing SAM innovation and its conceptual spread, while also advancing understanding through internal consolidation, interpretation, reflection, and communication (Foxcroft 2011).

In spite of this rich journey, SAM is not yet internalized across all pillars of SANParks' business or all constituent parks under its care. Conventional approaches to measuring achievement in complicated environments are constraining SANParks' overall approach, and SAM remains primarily confined to the conservation decision-making domain, in which embracing uncertainty is seen as appropriate. Tensions, between the domains of the complicated and the complex (sensu Snowden and Boone 2007), driven also by the escalating audit and governmental tick box indicator reporting culture, are ongoing and span various governance levels, requiring a balanced approach to coexist meaningfully if indeed the imperative of adaptive thinking is to become more mainstream. In addition, there is a mismatch in the focus of research that examines the nature of development and change within the spheres of ecology, overall conservation management, and governance. Although ecological change research has received significant attention, the realms of governance and governance-related research are still largely under-represented. Understanding and evaluating these changes is important to be able to interpret whether these have been successful, and to what extent, and requires reputable systemic and/or alternate methods of enquiry and evaluation. Finally, and in the true spirit of adaptive management, a number of differing emergent alternatives are possible as future trajectories for SANParks, constrained only by an ongoing willingness to learn and change.

\section{Responses to this article can be read online at:} http://www.ecologyandsociety.org/issues/responses. $\mathrm{php} / 6338$

\section{Acknowledgments:}

Sandra MacFadyen is acknowledged for preparing Fig. 1. We thank Kevin Rogers for comments on an early draft of this manuscript as well as Dirk Roux and Richard Stirzaker for insightful early reviews. Four anonymous reviewers gave both critical and encouraging comments, which focused and strengthened this manuscript.

\section{LITERATURE CITED}

Berkes, F., J. Colding, and C. Folke. 2002. Navigating socialecological systems: building resilience for complexity and change. Cambridge University Press, Cambridge, UK.

Bestbier, R., K. Rogers, A. Blackmore, J. Kruger, L. Nel, and H. Biggs. 1996. Guidelines for goal-orientated conservation. Centre for Water in the Environment, Report No. 1/96, University of the Witwatersrand, South Africa.

Biggs, H. C., C. M. Breen, and C. G. Palmer. 2008. Engaging a window of opportunity: synchronicity between a regional river conservation initiative and broader water law reform in South
Africa. International Journal of Water Resources Development 24 (3):329-343. http://dx.doi.org/10.1080/07900620802127275

Biggs, H. C., C. M. Breen., R. Slotow, S. Freitag, and M. Hockings. 2011. How assessment and reflection relate to more effective learning in adaptive management. Koedoe 53(2): Art. \#1001, 13 pages. http://dx.doi.org/10.4102/koedoe.v54i1.1001

Biggs, H. C., and K. H. Rogers. 2003. An adaptive system to link science, monitoring and management in practice. Pages 59-80 in J. du Toit, K. H. Rogers, and H. C. Biggs, editors. The Kruger experience: ecology and management of savanna heterogeneity. Island, Washington, D.C., USA.

Braack, L. E. O. 1997. A revision of parts of the management plan for the Kruger National Park. Volumes 7 and 8. Internal report, Kruger National Park, Skukuza, South Africa.

Braack, L. E. O., and P. Novellie. 1997. Kruger National Park management plan review: proceedings of discussion meetings held intermittently between July 1996 and April 1997. Internal report, Kruger National Park, Skukuza, South Africa.

Breen, C. M., M. Dent, J. Jaganyi, B. Madikizela, J. Maganbeharie, A. Ndlovu, J. O'Keeffe, K. Rogers, M. Uys, and F. Venter. 2000. The Kruger National Park Rivers Research Programme final report, incorporating the contract report and the review report. Water Research Commission report no TT 130/00, April 2000. Water Research Commission, Pretoria, South Africa.

Bridges, W. 1991. Managing transitions: making the most of change. Addison-Wesley, Reading, Massachusetts, USA.

Carruthers, J. 2007. Conservation and wildlife management in South African National Parks 1930s-1960s. Journal of the History of Biology 41:203-236. http://dx.doi.org/10.1007/s10739-007-9147-3

Carruthers, J., A. Boshoff, R. Slotow, H. C. Biggs, G. Avery, and W. Matthews. 2008. The elephant in South Africa: history and distribution. Pages 23-83 in R. J. Scholes and K. G. Mennell, editors. Elephant management: a scientific assessment for South Africa. Witwatersrand University Press, Johannesburg, South Africa.

Cowan, G. I. 2006. Management plan framework. Guidance for the development of management plans in terms of the national environmental management: Protected areas act (Act 57 of 2003). Department of Environmental Affairs and Tourism, Pretoria, South Africa.

Cullen, J. B., J. L. Johnson, and T. Sakano. 2000. Success through commitment and trust: the soft side of strategic alliance management. Journal of World Business 35(3):223-240. http://dx. doi.org/10.1016/S1090-9516(00)00036-5

Driver, A., K. Maze, M. Rouget, A. T. Lombard, J. Nel, J. K. Turpie, R. M. Cowling, P. Desmet, P. Goodman, J. Harris, Z. Jonas, B. Reyers, K. Sink, and T. Strauss. 2005. National spatial biodiversity assessment: priorities for biodiversity conservation in South Africa. Strelitzia 17. South African National Biodiversity Institute, Pretoria, South Africa.

du Toit, J., K. H. Rogers, and H. C. Biggs, editors. 2003. The Kruger experience: ecology and management of savanna heterogeneity. Island, Washington, D.C., USA. http://dx.doi. org/10.2989/16085910409503802 
Foxcroft, L. C., editor. 2011. The strategic adaptive management special edition. 53(2):1-211. [online] URL: http://www.koedoe.co. za/index.php/koedoe/issue/view/82

Fulton, D. C., M. J. Manfredo, and J. Lipscomb. 1996. Wildlife value orientations: a conceptual and measurement approach. Human Dimensions of Wildlife 1(2):24-47. http://dx.doi. org/10.1080/10871209609359060

Gaylard, A., N. Owen-Smith, and J. Redfern. 2003. Surface water availability: implications for heterogeneity and ecosystem processes. Pages 171-188 in J. du Toit, K. H. Rogers, and H. C. Biggs, editors. The Kruger experience: ecology and management of savanna heterogeneity. Island, Washington, D.C., USA.

Grant, R., T. Sherwill, K. Rogers, H. C. Biggs, S. Freitag, M. Hofmeyr, and M. Joubert. 2008a. A framework for developing and implementing management plans for South African National Parks. SANParks, Pretoria, South Africa.

Grant, R., T. Sherwill, K. Rogers, H. C. Biggs, S. Freitag, M. Hofmeyr, D. Pienaar, and M. Joubert. 2008b. An introduction to a new elephant management policy for South African National Parks. SANParks, Pretoria, South Africa.

Holling, C. S. 1978. Adaptive environmental assessment and management. John Wiley and Sons, Chichester, UK.

Holling, C. S. 2001. Understanding the complexity of economic, ecological and social systems. Ecosystems 4:390-405. http://dx. doi.org/10.1007/s10021-001-0101-5

Holness, S. D., and H. C. Biggs. 2011. Systematic conservation planning and adaptive management. Koedoe 53(2):9 pages. http:// dx.doi.org/10.4102/koedoe.v54i1.1029

Jones, G. 2009. The adaptive management system for the Tasmanian wilderness world heritage area - linking management planning and effectiveness evaluation. Pages 227-257 in C. Allan and G. H. Stankey, editors. Adaptive environmental management: a practitioners guide. Springer and CSIRO, Collingwood, Australia. [online] URL: http://www.parks.tas.gov.au/file.aspx? $\underline{\mathrm{id}=15135}$

Kingsford, R. T., H. C. Biggs, and S. R. Pollard. 2010. Strategic adaptive management in freshwater protected areas and their rivers. Biological Conservation 144:1194-1203. http://dx.doi. org/10.1016/j.biocon.2010.09.022

Kingsford, R. T., and H. C. Biggs. 2012. Strategic adaptive management guidelines for effective conservation of freshwater ecosystems in and around protected areas of the world. IUCN WCPA Freshwater Taskforce, Australian Wetlands and Rivers Centre, Sydney, Australia. [online] URL: http://www.wetrivers. unsw.edu.au/files/Strategic-Adaptive-Management_2012.pdf

Kinnaman, M. L., and M. R. Bleich. 2004. Collaboration: aligning resources to create and sustain partnerships. Journal of Professional Nursing 20(5):310-322. http://dx.doi.org/10.1016/j. profnurs.2004.07.009

Kotliar, N. B., and J. A. Wiens. 1990. Multiple scales of patchiness and patch structure: a hierarchical framework for the study of heterogeneity. Oikos 59:253-260. http://dx.doi.org/10.2307/3545542

Levin, S. A. 1999. Fragile dominion: complexity and the commons. Perseus, Cambridge, UK.
Mabunda, D., D. J. Pienaar, and J. Verhoef. 2003. The Kruger National Park: a century of management and research. Pages 3-21 in J. du Toit, K. H. Rogers, and H. C. Biggs, editors. The Kruger experience: ecology and management of savanna heterogeneity. Island, Washington, D.C., USA.

Mackenzie, J. A., A. L. van Coller, and K. H. Rogers. 1999. Rulebased modeling for management of riparian systems. Water Research Commission Report No 813/1/99. Water Research Commission, Pretoria, South Africa.

Margules, C. R., and R. L. Pressey. 2000. Systematic conservation planning. Nature 405:243-253. http://dx.doi.org/10.1038/35012251

McLoughlin, C. A., A. Deacon, H. Sithole, and T. Gyedu-Ababio. 2011. History, rationale, and lessons learned: thresholds of potential concern in Kruger National Park river adaptive management. Koedoe 53(2):75-101. http://dx.doi.org/10.4102/ koedoe.v54i1.996

Nkhata, A. B., C. M. Breen, and W. A. Freimund. 2008. Resilient social relationships and collaboration in the management of social-ecological systems. Ecology and Society 13(1): 2 [Online] URL: http://www.ecologyandsociety.org/vol13/iss1/art2/

O'Keeffe, J., and K. H. Rogers. 2003. Heterogeneity and management of the lowveld rivers. Pages 447-468 in J. du Toit, K. H. Rogers, and H. C. Biggs, editors. The Kruger experience: ecology and management of savanna heterogeneity. Island, Washington, D.C., USA.

Owen-Smith, N., G. I. H. Kerley, B. Page, R. Slotow, and R. J. van Aarde. 2006. A scientific perspective on the management of elephants in the Kruger National Park and elsewhere. South African Journal of Science 102:389-394. [online] URL: http:// www.ceru.up.ac.za/downloads/owen_smith_2006_scientific_perspective. pdf

Patton, M. Q. 2010. Developmental evaluation, applying complexity concepts to enhance innovation and use. Guilford, New York, New York, USA.

Pickett, S. T. A., M. L. Cadenasso, and T. L. Bening. 2003. Biotic and abiotic variability as key determinants of savanna heterogeneity at multiple spatiotemporal scales. Pages 22-40 in J. $\mathrm{du}$ Toit, K. H. Rogers, and H. C. Biggs, editors. The Kruger experience: ecology and management of savanna heterogeneity. Island, Washington, D.C., USA.

Pollard, S., H. Biggs, and D. du Toit. 2008. Towards a socioecological systems view of the Sand River catchment, South Africa. An exploratory resilience analysis. Water Research Commission report no. TT 364/08. Water Research Commission, Pretoria, South Africa.

Pollard, S., H. Biggs, and D. R. Du Toit. 2014. A systemic framework for context-based decision making in natural resource management: reflections on an integrative assessment of water and livelihood security outcomes following policy reform in South Africa. Ecology and Society 19(2): 63. http://dx.doi.org/10.5751/ ES-06312-190263

Pollard, S., and D. du Toit. 2007. Guidelines for strategic adaptive management: experiences from managing the rivers of the Kruger National Park. Report of UNEP/GEF project No GF/2713-03-4679, Ecosystems, Protected Areas and People 
Project. UNEP/GEF, Nairobi, Kenya. [online] URL: ftp://ftp. sanparks.org/Kruger/IUCN_Rivers/pollard\&dutoit(2005).pdf

Pollard, S., C. Shackleton, and J. Carruthers. 2003. Beyond the fence: people and the lowveld landscape. Pages 422-446 in J. du Toit, K. H. Rogers, and H. C. Biggs, editors. The Kruger experience: ecology and management of savanna heterogeneity. Island, Washington, D.C., USA.

Stockholm Resilience Centre. 2013. Regime shifts database. Stockholm Resilience Centre, Stockholm, Sweden. [online] URL: http://www.regimeshifts.org/

Rist, L., B. M. Campbell, and P. Frost. 2013. Adaptive management: where are we now? Environmental Conservation 40 (1):5-18. http://dx.doi.org/10.1017/S0376892912000240

Rogers, K. H. 2003. Adopting a heterogeneity paradigm: implications for management of protected savannas. Pages 41-58 in J. du Toit, K. H. Rogers, and H. C. Biggs, editors. The Kruger experience: ecology and management of savanna heterogeneity. Island, Washington, D.C., USA.

Rogers, K. H., and R. Bestbier. 1997. Development of a protocol for the definition of the desired state of riverine systems in South Africa. Department of Environmental Affairs and Tourism, Pretoria, South Africa.

Rogers, K. H., and Biggs, H. C. 1999. Integrating indicators, endpoints and value systems in the strategic management of the Kruger National Park. Freshwater Biology 41:439-451. http://dx. doi.org/10.1046/j.1365-2427.1999.00441.X

Rogers, K. H., and J. O'Keeffe. 2003. River heterogeneity: ecosystem structure, function and management. Pages 189-218 in J. du Toit, K. H. Rogers, and H. C. Biggs, editors. The Kruger experience: ecology and management of savanna heterogeneity. Island, Washington, D.C., USA.

Rokeach, M. 1973. The nature of human values. Free Press, New York, New York, USA.

Roux, D. J., and L. C. Foxcroft. 2011. The development and application of strategic adaptive management within South African National Parks. Koedoe 52(2):5 pages. http://dx.doi. org/10.4102/koedoe.v54i1.1049

South African National Parks (SANParks). 2013. Regional ecologists; bridging science and management at SANParks. In SANParks Research Report 2012. South African National Parks, Pretoria, South Africa. [online] URL: http://www.sanparks.org/ conservation/reports/research report.php

Scholes, B., and K. Mennell. 2008. Elephant management: a scientific assessment for South Africa. Wits University Press, Johannesburg, South Africa.

Snowden, D. J., and M. E. Boone. 2007. A leader's framework for decision-making. Harvard Business Review November 2007:1-8. [online] URL: http://www.mpiweb.org/CMS/uploadedFiles/ Article $\% 20$ for $\% 20$ Marketing $\% 20-\% 20$ Mary $\% 20$ Boone.pdf

Stankey, G. H., R. N. Clark, and B. T. Borman. 2005. Adaptive management of natural resources: theory, concepts and management institutions. Pacific Northwest Research Station general technical report PNW-GTR-654. United States
Department of Agriculture, Forest Service, Washington, D.C., USA. [online] URL: http://www.fs.fed.us/pnw/pubs/pnw gtr654. pdf

Tambling, C. J., S. M. Ferreira, J. Adendorff, and G. I. H. Kerley. 2013. Lessons from management interventions: consequences for lion-buffalo interactions. South African Journal of Wildlife Research 43(1):1-11. http://dx.doi.org/10.3957/056.043.0116

van Coller, A. L. 1993. Riparian vegetation of the Sabie River: relating spatial distribution patterns to characteristics of the physical environment. Thesis. University of the Witwatersrand, Johannesburg, South Africa.

van Wilgen B. W., N. Govender, and H. C. Biggs. 2007. The contribution of fire research to fire management: a critical review of a long-term experiment in the Kruger National Park, South Africa. International Journal of Wildland Fire 16:519-530. http:// dx.doi.org/10.1071/WF06115

van Wilgen, B. W., W. S. W. Trollope, H. C. Biggs, A. L. F. Potgieter, and B. H. Brockett. 2003. Fire as a driver of ecosystem variability. Pages 149-170 in J. du Toit, K. H. Rogers, and H. C. Biggs, editors. The Kruger experience: ecology and management of savanna heterogeneity. Island, Washington, D.C., USA.

Van Wyk, P., and N. Fairall. 1969. The influence of the African elephant on the vegetation of the Kruger National Park. Koedoe12:57-89. http://dx.doi.org/10.4102/koedoe.v12i1.747

Walters, C. J. 1986. Adaptive management of renewable resources. MacMillan, New York, New York, USA.

Westley, F., and H. Vredenburg. 1997. Interorganizational collaboration and the preservation of global biodiversity. Organization Science 8(4):381-403. http://dx.doi.org/10.1287/ orsc.8.4.381 